J. Range Manage.

48:410-416 September 1995

\title{
Use of degree-days in multiple-temperature experiments
}

\author{
J.T. ROMO AND L.E. EDDLEMAN
}

Authors are associate professor, Dep. of Crop Science and Plant Ecology, Univ. of Saskatchewan, Saskatoon, Saskatchewan, S7N 5A8, and prafessor, Dep. of Rangeland Resources, Oregon State Univ., Corvallis, Ore. 97331. Corresponding author is $J T R$

\begin{abstract}
This research compared results from germination and growth when the experiment duration was chronologically set or based on degree-days. Seeds of smooth brome (Bromus inermis Leyss.), plains rough fescue (Festuca altaica Trin. subsp. hallii (Vasey) Harms), prairie coneflower (Ratibida columnifera (Nutt.) Woot. and Standl.), and silver sagebrush (Artemisia cana Pursh.) were germinated at $5,10,15,20$, and $25^{\circ} \mathrm{C}$ for 28 days or 400 degreedays (Base temperature $=0^{\circ} \mathrm{C}$ ). Root and shoot weights of seedings of these species were compared at $5,10,15,20,25$ and $30^{\circ} \mathrm{C}$ after growing them 20 days or 200 degree-days. With the exception of prairie coneflower, optimal temperatures for germination were 2 to $4^{\circ} \mathrm{C}$ lower when incubated 400 degree-days compared to 28 days. Total germination for prairie coneflower was not significantly different $(P=0.454)$ at 28 days or 400 degreedays. Interacting effects of the duration of experiments and temperature significantly $(P \leq 0.001)$ influenced root and shoot weight of all species. Except for shoot weight of smooth brome, predicted cptimum temperatures for root and shoot growth were 7 to $21^{\circ} \mathrm{C}$ lower at 200 degree-days than 20 days. These experiments illustrate that results from germination and growth studies can vary substantially depending on whether chronological time or degree-days are used as the end point. Thus, ecological interpretotions or management recommendations can be quite different. Degree-days may be more meaningful than chronological units for germination and growth studies because they integrate time and temperature. The use of degree-days as an end point for experiments rather than chronological time deserves further consideration by researchers.
\end{abstract}

Key Words: Ariemisia cana, Bromus inermis, Festuca altaica subsp. hallii, germination, Ratibida columnifera, root growth, shoot growth, thermal units

Researchers have long been interested in studying germination and plant responses to temperature. Comparisons are often made between temperatures after incubating seeds or growing plants in controlled conditions for set periods of time. Results from these studies are then used to make ecological interpretations or man-

Manuscript accepted 30 Nov. 1994. agement prescriptions. However, because plant processes are temperature dependent (Johnson and Thomley 1985), erroneous conclusions may be drawn if time is used as the independent variable at various temperatures. Generally as temperatures rise, plant processes increase to a maximum, declining above some optimum (Grace 1988). When results from experiments at different temperatures are compared, arbitrarily set chronological time limits introduce time as a confounding factor because equal thermal units do not accumulate at each temperature.

Degree-days or thermal units have been successfully utilized to describe or predict insect phenology (Dennis et al. 1986, Dennis and Kemp 1988), bud burst in trees (Thomson and Moncrieff 1982, Hunter and Lechowicz 1992), pollen shedding (Boyer 1973), flowering in several range plants (White 1979), anthesis and maturity of wheat (Triticum aestivum L.) and com (Zea mays L.) (Gilmore and Rodgers 1958, Cross and Zuber 1972, Davidson and Campbell 1983, Bauer et al. 1984), growth of forage species (Holt and Haferkamp 1987, Frank and Hofmann 1989, Frank 1991, Gillen and Ewing 1992, Harrison and Romo 1994) and germination and emergence of several species (Carberry and Campbell 1989, Jordan and Haferkamp 1989). Degree-days have, however, received limited use as time limits where results are compared from experiments conducted at different temperatures. The purpose of the research reported here was to test whether interpretation of data from germination and growth studies at several temperatures would be significantly different if the duration of experiments is chronologically set or based on degree-days.

\section{Materials and Methods}

In 1987 seeds of plains rough fescue (Festuca altaica subsp. hallii (Vasey) Harms) and smooth brome (Bromus inermis Leyss.) were collected at the University of Saskatchewan's Kernen Prairie (Pylypec 1986), $1 \mathrm{~km}$ east of Saskatoon. Prairie coneflower (Ratibida columnifera (Nutt.) Woot. and Standl.) and silver sagebrush (Artemisia cana Pursh.) were collected at the University of Saskatchewan's Matador Research Station (Coupland et al. 1974), approximately $70 \mathrm{~km}$ north of Swift Current, Saskatchewan. The native species were selected because their seeds were readily available, they were different life forms, 
and they were from different habitats. Smooth brome was chosen because it is a naturalized exotic that has been subject to intense selection pressure by forage breeders. About 2 weeks after collection seeds were cleaned with hand-held sieves and stored in paper envelopes in darkness in the laboratory.

\section{Germination Experiments}

In germination experiments, durations of 28 days and 400 degree-days, and temperatures of $5,10,15,20$, or $25^{\circ} \mathrm{C}$ were factorially applied in a randomized complete block design with 4 replicates of 50 seeds for each species. Daily incubation temperatures were used to calculate accumulated degree-days using a base temperature of $0^{\circ} \mathrm{C}(\mathrm{Eq} .1)$.

$$
\begin{aligned}
& \text { Accumulated degree-days }=\sum\left[\text { (Daily temperature }{ }^{\circ} \mathrm{C}-\right.\text { Base } \\
& \text { temperature } \\
& \left.{ }^{\circ} \mathrm{C} / 2\right]
\end{aligned}
$$

The seeds were placed in closed petri dishes on 1-mm thick germination paper that was moistened with distilled water and incubated in darkness. Germination was checked weekly and germinated seeds were removed; distilled water was added to the petri dishes to keep the seeds moist. During the germination checks seeds were briefly exposed to light. Seeds of the grasses were considered germinated when the radicle and plumule were both $\geq 5-\mathrm{mm}$ long whereas silver sagebrush and prairie coneflower were counted if the cotyledons were reflexed and the radicle was $\geq 5-\mathrm{mm}$ long.

Total germination data for each species were analyzed with factorial analysis of variance (Petersen 1985) after transforming the percentages with arcsin $\sqrt{\bar{p}}$ (Snedecor and Cochran 1980). When the temperature-by-duration interaction was significant $(P \leq 0.05)$, data from the 2 experiments were separated and the best-fit regression equations (Petersen 1985) were determined after the data were back-transformed. If the interaction was not significant $(P \leq 0.05)$, the significance of the duration of the experiment and temperature was considered and the best-fit $(P \leq 0.05)$ regression equation was calculated.

\section{Seedling Growth}

In the seedling growth experiments durations of 20 days and 200 degree-days (Eq. 1) (Base temperature $=0^{\circ} \mathrm{C}$ ) and temperaanres of $5,10,15,20,25$, or $30^{\circ} \mathrm{C}$ were factorially applied in a randomized complete block design with 4 replicates. Seeds of each species were incubated in darkness at $20^{\circ} \mathrm{C}$ in petri dishes that were prepared as described above. Seedlings at 2 days of age were individually transplanted to pots containing premoistened "Redi-earth" poting medium. These plants were grown in growth chambers and watered at 2-day intervals. All growth chambers provided a 12 hour photoperiod standardized at $395 \mu \mathrm{mol} \mathrm{m} \mathrm{m}^{-2} \mathrm{~s}^{-1}$. At 20 days or 200 degree-days, plants of each species were removed from the pots, and the potting medium was carefully removed from the roots by washing in water. The roots were separated from the shoots, and both were dried at $60^{\circ} \mathrm{C}$ for 48 hours and weighed.

Root and shoot weights for each species were analyzed with factorial analysis of variance (Petersen 1985). When the temperature-by-duration interaction was significant $(P \leq 0.05)$, data from the 2 experiments were separated and the best-fit regression equations $(P \leq 0.05)$ were determined over the temperature range (Petersen 1985).

\section{Results}

\section{Germination Experiment}

With the exception of prairie coneflower, the duration-by-temperature interaction significantly $(P \leq 0.001)$ influenced total germination (Table 1). This highly significant interaction indicates that temperature influenced germination uniquely depending on whether the length of the experiment was chronologically set or based on degree-days. The non-significant $(P=0.454)$ temperature-by-duration interaction for prairie coneflower indicates that the criterion for terminating experiments was not important.

When data from the 2 experiments were combined in regres-

Table 1. Analyses of variance for total germination of seeds incubated at constant temperatures of $5,10,15,20$, or $25^{\circ} \mathrm{C}$ for 28 days or 400

\begin{tabular}{|c|c|c|c|c|}
\hline Source & D.F. & Mean Square & $\mathrm{F}$ & $\mathbf{P}$ \\
\hline & \multicolumn{4}{|c|}{........ Smooth brome $\ldots \ldots$} \\
\hline Replicate (R) & 3 & 58 & 1.2 & 0.342 \\
\hline Temperature (T) & 4 & 2566 & 51.3 & $<0.001$ \\
\hline Duration (D) & 1 & 270 & 5.4 & 0.028 \\
\hline $\mathrm{D} \times \mathrm{T}$ & 4 & 476 & 9.5 & $<0.001$ \\
\hline \multirow[t]{2}{*}{ Error } & 27 & 50 & & \\
\hline & \multicolumn{4}{|c|}{ _ } \\
\hline $\mathbf{R}$ & 3 & 43 & 1.0 & 0.396 \\
\hline $\mathrm{T}$ & 4 & 2736 & 65.8 & $<0.001$ \\
\hline $\mathrm{D}$ & 1 & 84 & 2.0 & 0.166 \\
\hline $\mathrm{D} \times \mathrm{T}$ & 4 & 170 & 4.1 & 0.010 \\
\hline \multirow[t]{2}{*}{ Error } & 27 & 42 & & \\
\hline & \multicolumn{4}{|c|}{ _ } \\
\hline $\mathbf{R}$ & 3 & 21 & 0.3 & 0.826 \\
\hline $\mathrm{T}$ & 4 & 4990 & 72.1 & $<0.001$ \\
\hline D & 1 & 40 & 0.6 & 0.454 \\
\hline $\mathrm{D} \times \mathrm{T}$ & 4 & 147 & 2.1 & 0.105 \\
\hline \multirow[t]{2}{*}{ Error } & 27 & 69 & & \\
\hline & \multicolumn{4}{|c|}{ - Plains rough fescue } \\
\hline $\mathbf{R}$ & 3 & 67 & 1.3 & 0.308 \\
\hline $\mathrm{T}$ & 4 & 4412 & 82.7 & $<0.001$ \\
\hline D & 1 & 1082 & 20.3 & $<0.001$ \\
\hline $\mathrm{D} \times \mathrm{T}$ & 4 & 1512 & 28.3 & $<0.001$ \\
\hline Error & 27 & 53 & & \\
\hline
\end{tabular}
degree-days (Base temperature $=0^{\circ} \mathrm{C}$ ).

sion analyses, the predicted optimum temperature for germination of prairie coneflower was $15^{\circ} \mathrm{C}$ (Table 2, Fig. 1). Separate regression equations were developed for the 2 experiments for plains rough fescue, silver sagebrush, and smooth brome. For germination of silver sagebrush the predicted optimum was $12^{\circ} \mathrm{C}$ at 28 days and $8^{\circ} \mathrm{C}$ at 400 degree-days (Table 2, Fig. 2). The predicted optimum for germination of plains rough fescue was $16^{\circ} \mathrm{C}$ at 28 days and $12^{\circ} \mathrm{C}$ at 400 degree-days (Table 2, Fig. 3). Optimum temperatures for smooth brome germination were $18^{\circ} \mathrm{C}$ at 28 days and $16^{\circ} \mathrm{C}$ at 400 degree-days (Table 2, Fig. 4). Germination of the later 3 species was higher at lower temperatures at 400 degree-days than at $2 S$ days.

\section{Seedling Growth Experiment}

The interaction of duration-by-temperature significantly $(P \leq 0.001)$ influenced root and shoot weight of all species (Table 3 ). Therefore separate regression equations were developed for each species in the 


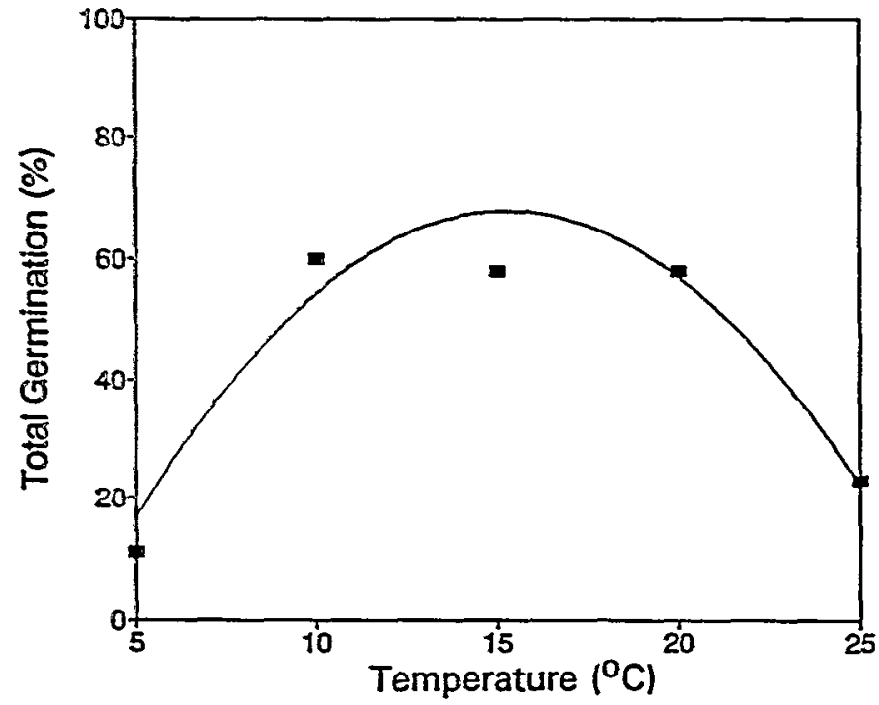

Fig. 1. Response curve for total germination of prairie coneflower incubated at $5,10,15,20$, or $25^{\circ} \mathrm{C}$ for 28 days or 400 degree-days. Each symbol is the mean of 8 replicates. The regression equation is presented in Table 2.

2 experiments. With the exception of shoot weight of smooth brome, predicted optimum temperatures were greater at 20 days than at 200 degree-days.

When grown for 20 days the predicted optimum temperature for shoot and root biomass of prairie coneflower was $\geq 30^{\circ} \mathrm{C}$ (Table 2, Fig. 5). In sharp contrast, the predicted optimum tem-

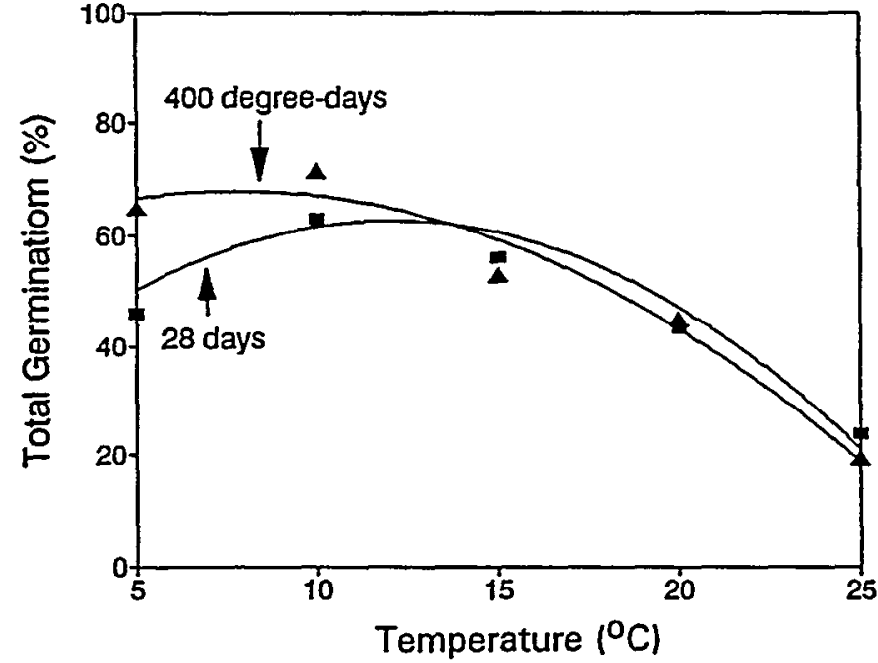

Fig. 2. Response curves for total germination of silver sagebrush incubated at $5,10,15,20$, or $25^{\circ} \mathrm{C}$ for 28 days (D) or 400 degreedays (A). Each symbol is the mean of 4 replicates. Regression equations are presented in Table 2.

peratures for shoot and root biomass were 17 and $15^{\circ} \mathrm{C}$, respectively, at 200 degree-days.

When silver sagebrush was grown for 20 days the predicted optimum for shoot biomass was $22^{\circ} \mathrm{C}$ (Table 3, Fig. 6); shoot weight did not differ over the $5-30^{\circ} \mathrm{C}$ range at 200 degree-days. Root growth increased from 5 to $21^{\circ} \mathrm{C}$ during the 20 day growth

Table 2. Regressicn equations for total germination, root and shoot biomass for 4 species. $\mathrm{X}$ is temperature $\left({ }^{\circ} \mathrm{C}\right)$.

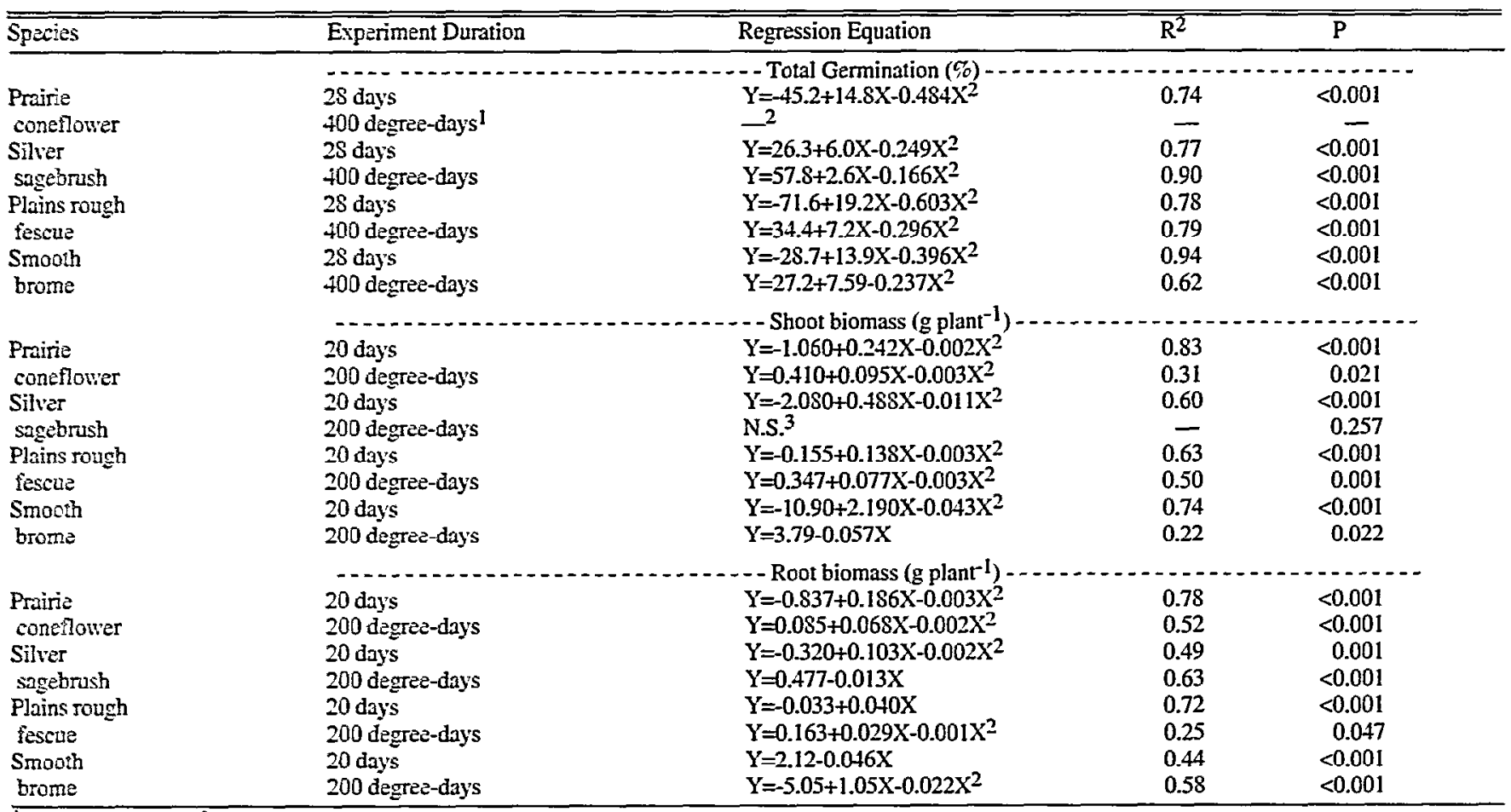

${ }_{1}$ Base temperature $=n^{3} \mathrm{C}$

2 Tutal gemuination at 28 days and 403 degree-days was not significantly different (See Table 1). Data from both experiments were pooled for regression analysis.

3 Regression equation not signifieant at $P \leq 0.05$. 


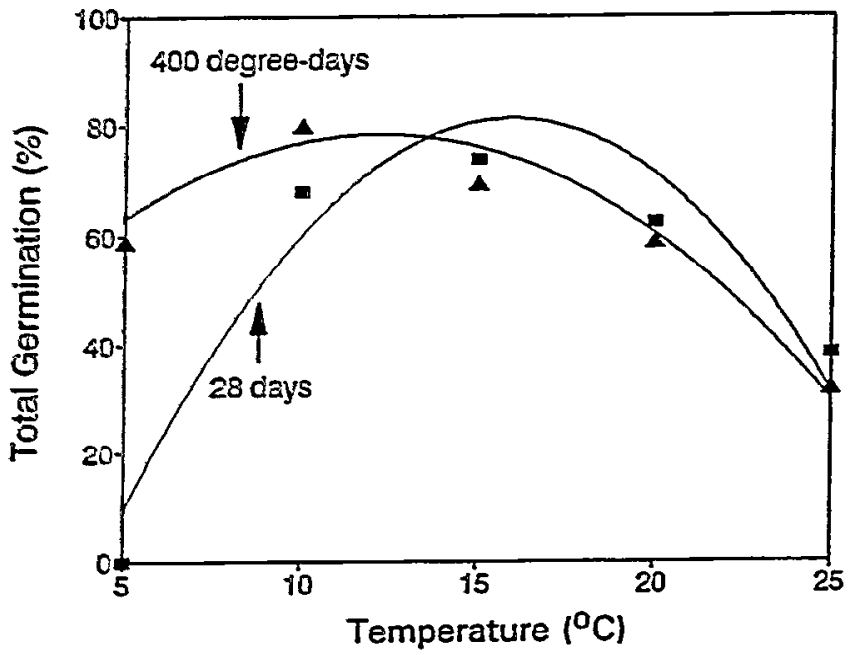

Fig. 3. Respanse curres for total germination of plains rough fescue incubated at $5,10,15,20$, or $25^{\circ} \mathrm{C}$ for 28 days (U) or 400 degreedays (A). Each symbol is the mean of 4 replicates. Regression equations are presented in Table 2.

period; however, over the $5-30^{\circ} \mathrm{C}$ range root biomass decreased linearly when grown 200 degree-days.

The predicted optimum temperature for shoot growth of plains rough fescue was $22^{\circ} \mathrm{C}$ at 20 days and $15^{\circ} \mathrm{C}$ at 200 degree-days (Table 2, Fig. 7). Root weight of plains rough fescue increased linearly from $5-30^{\circ} \mathrm{C}$ when grown for 20 days, but the predicted optimum was $16^{\circ} \mathrm{C}$ when seedlings were grown 200 degree-days.

The predicted optimum temperatures for shoot biomass of smooth brome were $26^{\circ} \mathrm{C}$ and $5^{\circ} \mathrm{C}$ when grown 20 days and 200 degree-days, respecrively (Table 3, Fig. 8). Root weight declined linearly over the $5-30^{\circ} \mathrm{C}$ range when seedlings were grown for

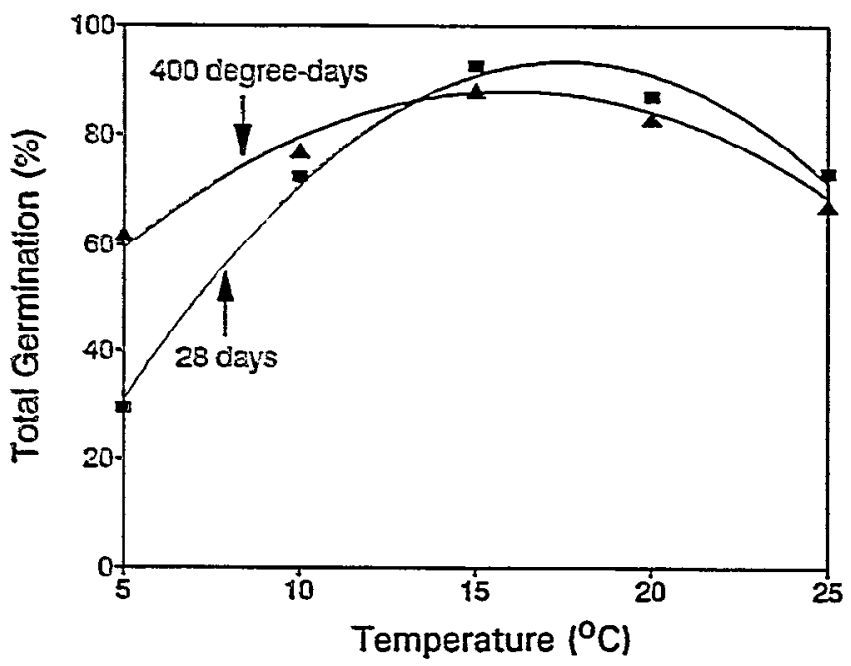

Fig. 4. Response curves for total germination of smooth brome incubated at $5,10,15,20,25$, or $30^{\circ} \mathrm{C}$ for 28 days $(\rightarrow)$ or 400 degreedays (A). Each symbol is the mean of 4 replicates. Regression equations are presented in Table 2.
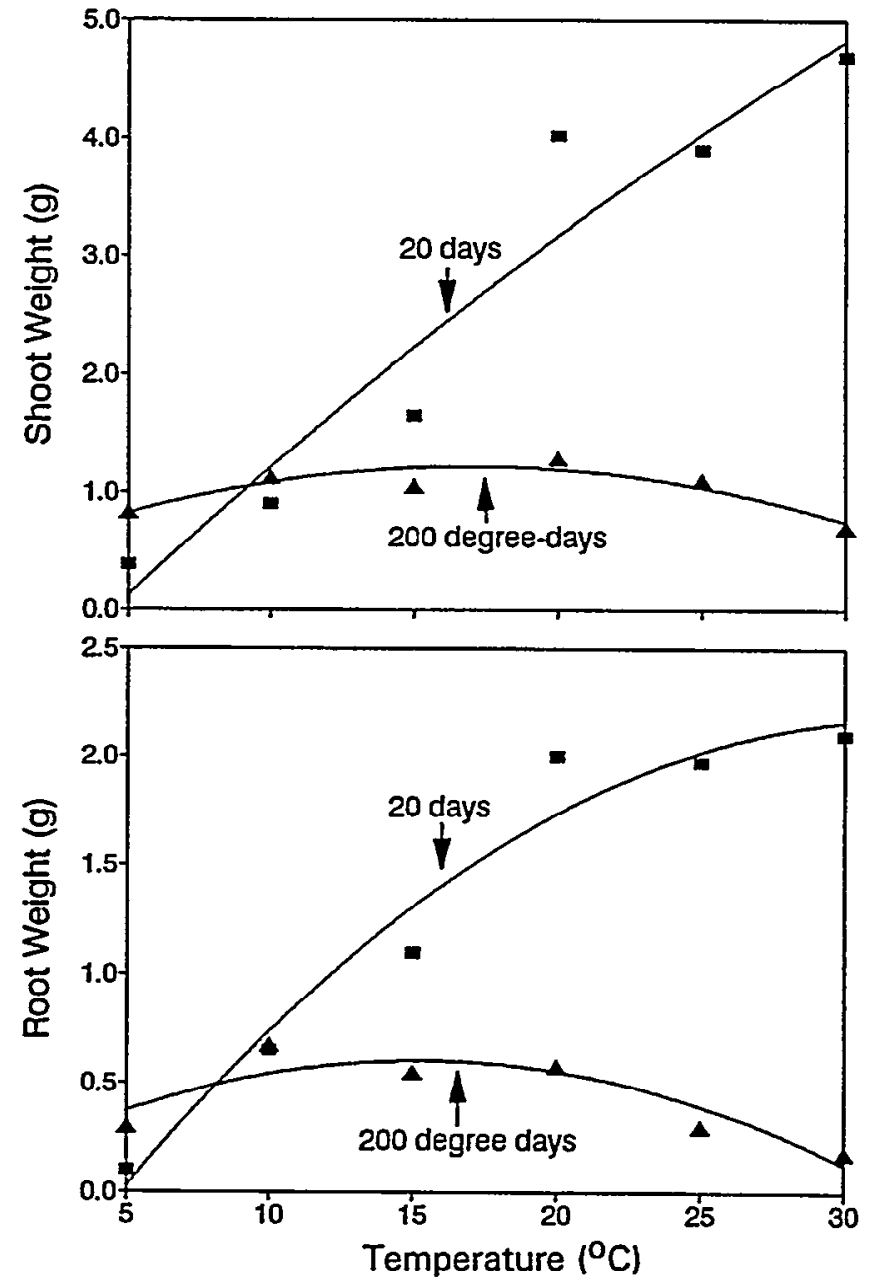

Fig. 5. Response curves for root and shoot growth of prairie coneflower seedlings grown at $5,10,15,20,25$, or $30^{\circ} \mathrm{C}$ for 20 days (I) or 200 degree-days (A). Each symbol is the mean of 4 replicates. Regression equations are presented in Table 2.

200 degree-days, but the optimum temperature was $24^{\circ} \mathrm{C}$ at 20 degree-days.

\section{Discussion}

Experiments where chronological time limits have been used have provided useful information for ecological interpretations and management. Utilizing chronological limits provides (1) comparisons with previously published data from studies of similar length, (2) short completion time for experiments, and (3) low costs of research. By contrast a disadvantage of using degreedays is that the period of experimentation may be increased and costs may also rise. For example in the present study 80 days were required at $5^{\circ} \mathrm{C}$ to accumulate 400 degree-days, but only 13.3 days were required at $30^{\circ} \mathrm{C}$.

How species respond to temperatures after exposure to certain temperatures for chronologically set periods of time are also easi- 
Table 3. Analyses of variance for root and shoot weight for seedlings grown at $5,10,15,20,25$ and $30^{\circ} \mathrm{C}$ for 20 days or 200 degree-days (Base temperature $=0^{\circ} \mathrm{C}$ ).

\begin{tabular}{|c|c|c|c|c|c|c|c|}
\hline Source & D.F. & $\begin{array}{c}\text { Mean } \\
\text { Square } \\
\text { Root Wh }\end{array}$ & $\underset{\text { eight }}{\mathrm{F}}$ & $\begin{array}{c}P \\
-2\end{array}$ & $\begin{array}{l}\text { Mfean } \\
\text { Square } \\
- \text { - Shoo }\end{array}$ & $\begin{array}{c}F \\
\text { Weigh }\end{array}$ & $\begin{array}{c}P \\
(g)--\end{array}$ \\
\hline & $\ldots$ & & - & Smaoth b & ome - - & ---1 & $\cdots$ \\
\hline Replicate (R) & 3 & 3.8 & 1.6 & 0.216 & 3.3 & 0.8 & 0.510 \\
\hline Temperature (T) & 5 & 17.6 & 7.2 & $<0.001$ & 109.7 & 26.1 & $<0.001$ \\
\hline Duration (D) & 1 & 157.3 & 64.5 & $<0.001$ & 826.7 & 197.0 & $<0.001$ \\
\hline $\mathrm{D} \times \mathrm{T}$ & 5 & 26.1 & 10.7 & $<0.001$ & 132.3 & 31.5 & $<0.001$ \\
\hline Error & 33 & 2.4 & & & 4.2 & & \\
\hline & & 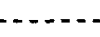 & $--S i$ & ver saget & ush - - - & & ---- \\
\hline$\Omega$ & 3 & 0.086 & 3.4 & 0.029 & 0.679 & 1.8 & 0.174 \\
\hline $\mathrm{T}$ & 5 & 0.082 & 3.2 & 0.018 & 3.546 & 9.2 & $<0.001$ \\
\hline D & 1 & 1.203 & 47.7 & $<0.001$ & 24.797 & 64.2 & $<0.001$ \\
\hline$D \times T$ & 5 & 0.296 & 11.7 & $<0.001$ & 3.703 & 9.6 & $<0.001$ \\
\hline Error & 33 & 0.025 & & & 0.386 & & \\
\hline $\mathbf{R}$ & 3 & 0.034 & 0.3 & 0.813 & 0.267 & 1.1 & 0.365 \\
\hline$T$ & 5 & 1.298 & 89.2 & $<0.001$ & 6.856 & 28.1 & $<0.001$ \\
\hline D & 1 & 9.541 & 12.1 & $<0.001$ & 29.925 & 122.6 & $<0.001$ \\
\hline $\mathrm{D} \times \mathrm{T}$ & 5 & 1.646 & 15.4 & $<0.001$ & 6.821 & 27.9 & $<0.001$ \\
\hline Error & 33 & 0.107 & & & 0.214 & & \\
\hline & & & -Plai & rougn I & $5-1$ & . & \\
\hline R & 3 & 0.083 & 3.3 & 0.033 & 0.016 & 0.3 & 0.794 \\
\hline$T$ & 5 & 0.284 & 11.3 & $<0.001$ & 0.559 & 10.0 & $<0.001$ \\
\hline D & 1 & 1.435 & 56.8 & $<0.001$ & 1.725 & 30.9 & $<0.001$ \\
\hline $\mathrm{D} \times \mathrm{T}$ & 5 & 0.362 & 14.3 & $<0.001$ & 0.217 & 3.9 & 0.007 \\
\hline EтTor & 33 & 0.025 & & & 0.056 & & \\
\hline
\end{tabular}

ly determined. If the duration of chronologically set experiments is sufficient for maximum germination at the lowest temperatures tested. there is no advantage of using degree-days and interpretation of results will not differ between the 2 techniques.

The use of degree-days becomes important when there is not a sufficient amount of germination at the low tempcrature using the chronologically set time period. Two parameters must be determined to use the degree-days approach: (1) the base temperature, and (2) the required number of degree-days. Base temperatures can be determined by regressing germination or growth on temperature (Amold 1959), or if base temperatures are not known, $0^{\circ} \mathrm{C}$ can be used (e.g. Bauer et al. 1984, Frank and Hoffmann 1989. Gillen and Ewing 1992, Romo et al. 1991, Grilz et al. 1994). Caution must be exercised when comparing species, genotypes, and different stages of growth for they have different base temperature thresholds (Wang 1960). If the base temperature is changed, appropriate adjustments in the length of study will be reguired at each temperature, but relationships between temperatures will not change. Similarly if higher or lower temperatures are included in the experiments, the length of study will need to be lengthened or shortened. The number of degree-days chosen for the length of experimentation is subject to the objectives of each study. It is most meaningful to set degree-day limits that are biologically meaningful and correspond with field conditions and the stages of growth being studied.

The degree-days concept assumes that development is linearly related to temperature between the base temperature and the optimum temperature (Sharpe and DeMichele 1977). In addition it is assumed a certain stage of development is achieved when a spe-
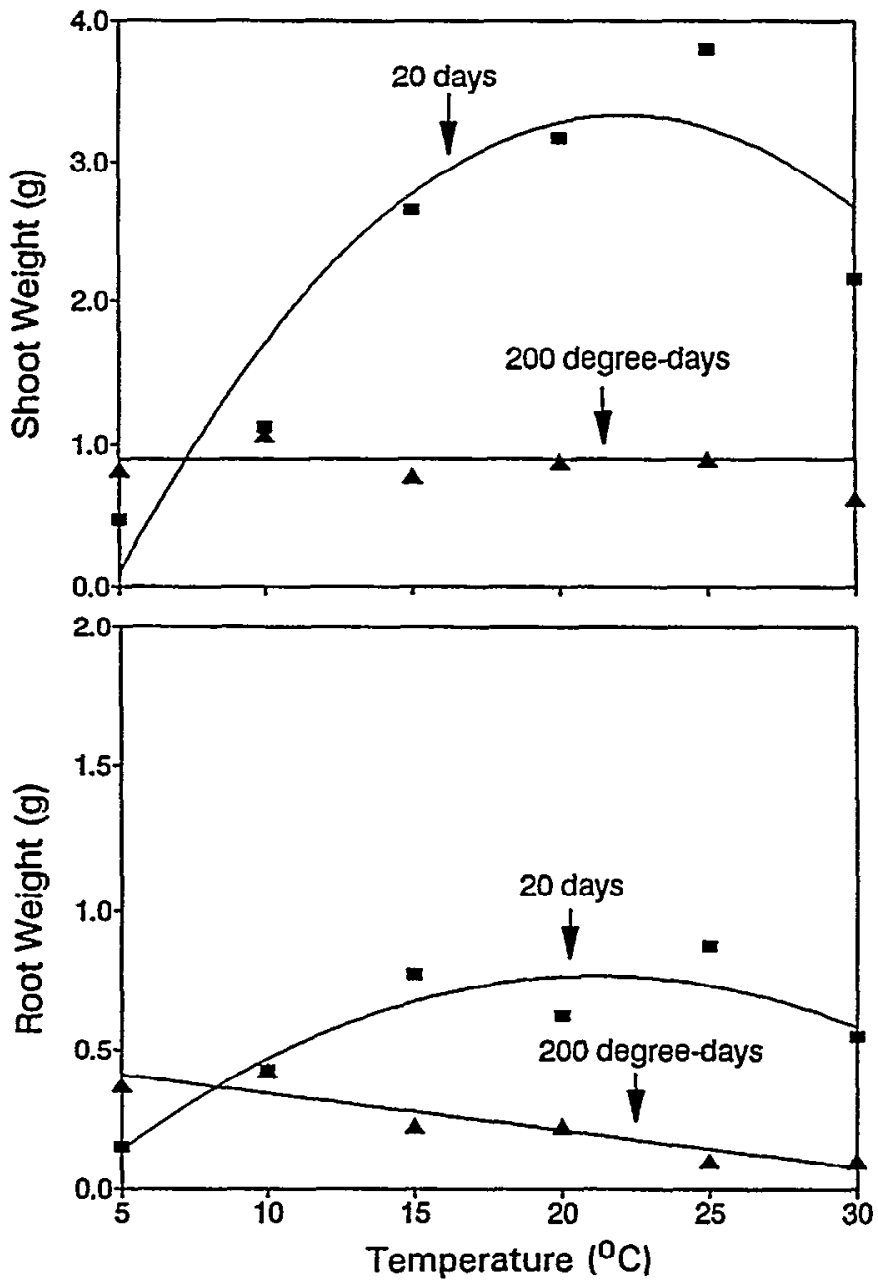

Fig. 6. Response curves for root and shoot growth of silver sagebrush seedlings grown at $5,10,15,20,25$, or $30^{\circ} \mathrm{C}$ for 20 days (i) or 200 degree-days (A). Each symbol is the mean of 4 replicates. Regression equations are presented in Table 2.

cific number of degree days have accumulated above the base temperature (Hunter and Lechowicz 1992). Thus, when germination and growth experiments are conducted for chronologically set time, it should not be unexpected to find temperature limitations as temperatures decline from the optimum. As a result, ecological interpretations or management recommendations can deviate considerably. For example, in the present study predicted temperatures for germination and growth from the experiments with chronologically set time limits would be warmer than those determined when degree-days were used.

Although constant temperatures were used in the present studies, the use of degree-days is not restricted to them. If alternating temperatures are chosen, degree-days can be calculated (Eq. 2).

Accumulated degree-days $=\sum\left[\left(\right.\right.$ Maximum temperature ${ }^{\circ} \mathrm{C}+$ Minimum temperature ${ }^{\circ} \mathrm{C}$ - Base temperature $\left.{ }^{\circ} \mathrm{C}\right) / 2$ ]

For example, emergence and growth of wild oat (Avena fatua L.) under several alternating temperature regimes were compared after standardizing with degree-days (Rooney et al. 1989). Romo et al. (1991) and Grilz et al. (1994) also used cumulative degreedays to determine the effects of increasing or decreasing tempera- 

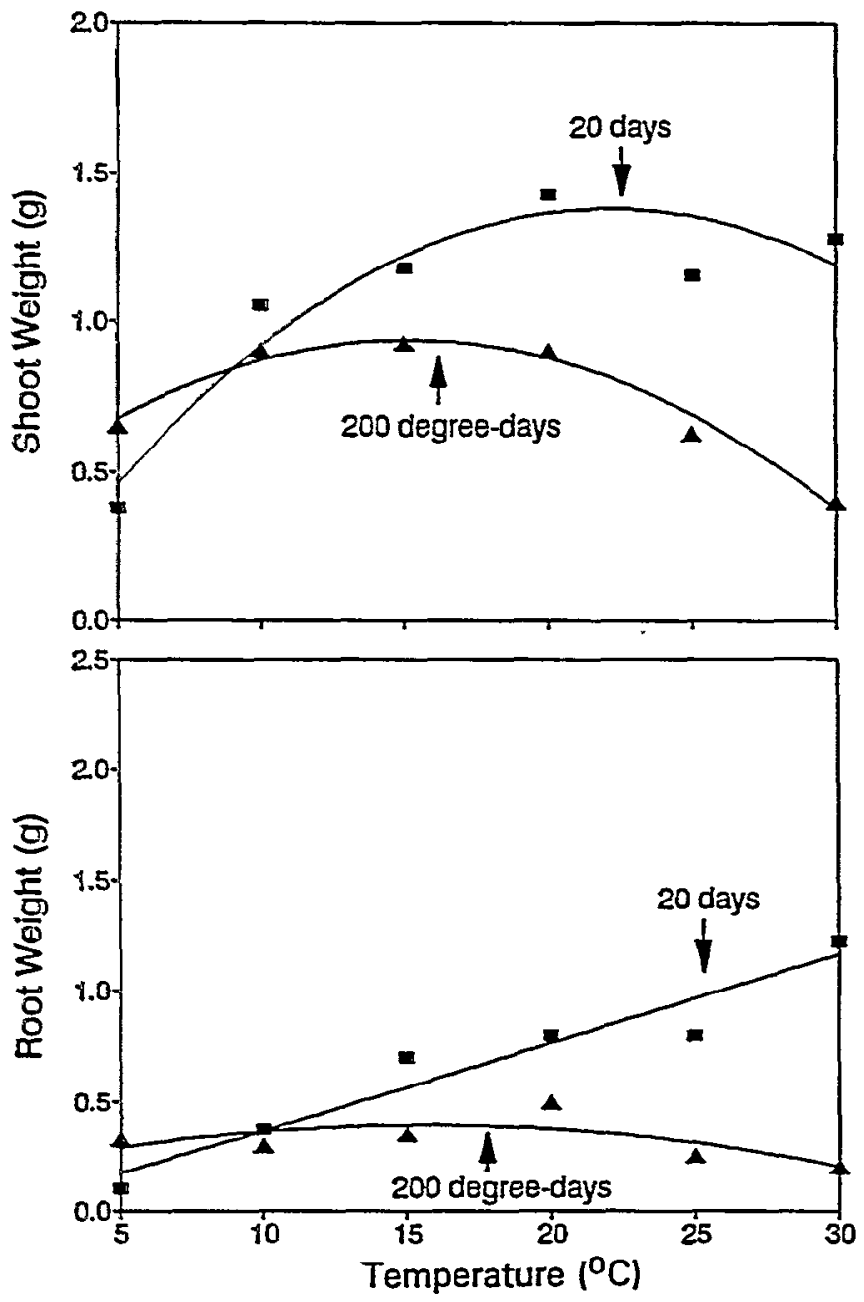

Fig. 7. Response curves for root and shoot growth of plains rough fescue seedilings grown at $5,10,15,20,25$, or $30^{\circ} \mathrm{C}$ for 20 days (in) or 200 degree-days (A). Each symbol is the mean of 4 replicates. Regression equations are presented in Table 2.

tures on germination of plains rough fescue and smooth brome, studies that would not have been possible without using degreedays.

Degree-days are biologically more meaningful than chronological units because they integrate time and temperature (Johnson and Thomley 1985). Thercfore degree-days reduce artificially introduced effects of time when results are compared from experiments that are conducted at different temperatures. Use of degree-days may also improve predictions of field performance from studies conducted under controlled environmental conditions. The applicability of degree-days in multiple-temperature germination and growth studies merits additional consideration and research.

\section{Literature Cited}

Arnold, C.Y. 1959. The determination and significance of the base temperature in a linear heat unit system. Proc. Amer. Soc. Hort. Sci. 74:430-415.
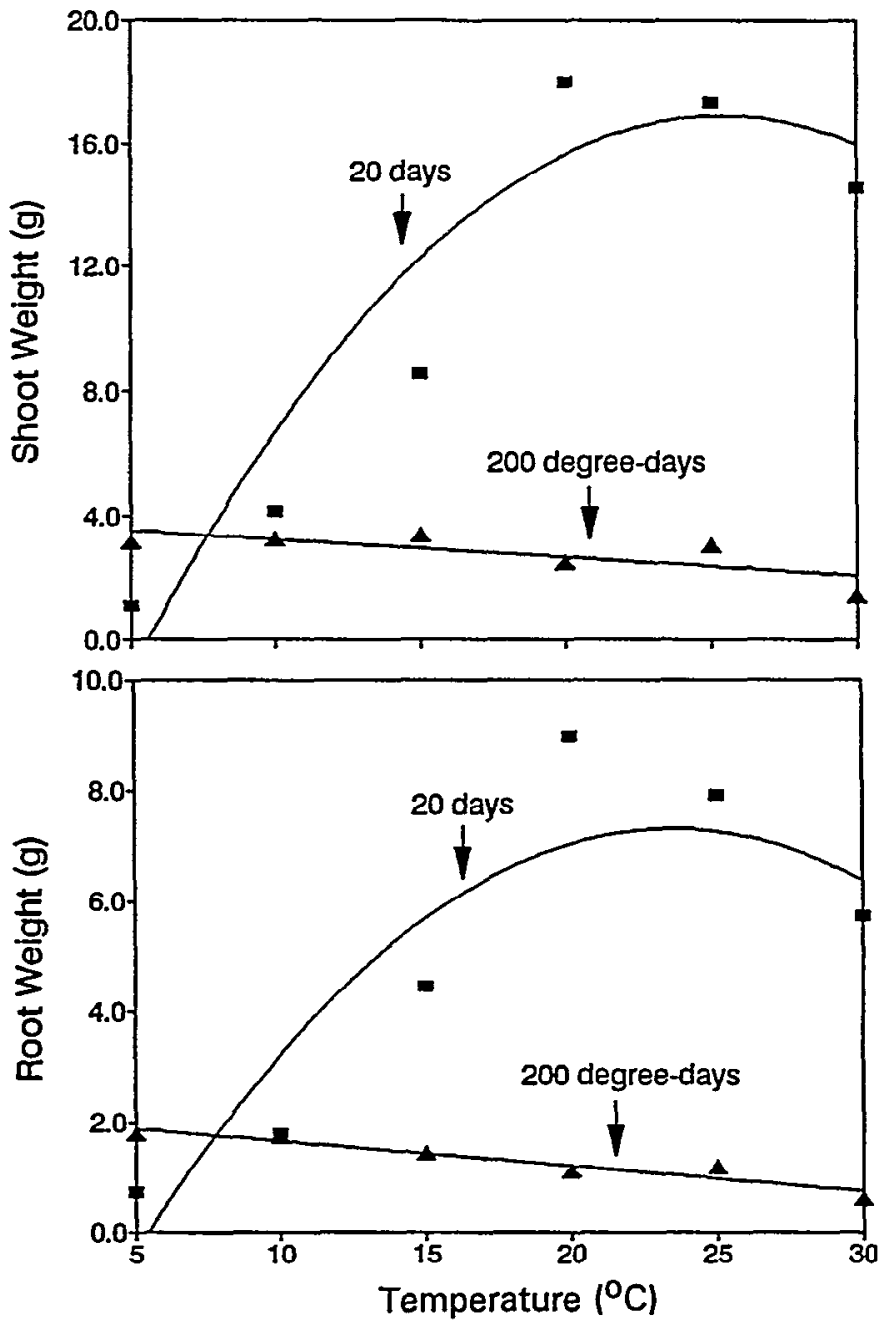

Fig. 8. Response curves for root and shoot growth of smooth brome seedlings grown at $5,10,15,20,25$, or $30^{\circ} \mathrm{C}$ for 20 days (i) or 200 degree-days ( $\triangle$ ). Each symbol is the mean of 4 replicates. Regression equations are presented in Table 2.

Bauer, A., A.B. Frank, and A.L. Black. 1984. Estimation of spring wheat leaf growth rates and anthesis from air temperature. Agron. J. 76:829-835.

Boyer, W.D. 1973. Air temperature, heat sums, and pollen shedding phenology of longleaf pine. Ecol. 54:420-426.

Carberry, P.S., and L.C. Campbell. 1989. Temperature parameters useful for modeling the germination and cmergence of pearl millet. Crop Sci. 29:220-223.

Coupland, R.T., J.R. Willard, and E.A. Ripley. 1974. Summary of activities, 1967-1974. Matador Project Tech. Rep. No. 69. Univ. of Saskatchewan.

Cross, H.Z., and M.S. Zuber. 1972. Prediction of flowering dates in maize based on different methods of estimating thermal units. Agron. J. 64:351-355.

Davidson, H.R., and C.A. Campbell. 1983. The effect of temperature, moisture and nitrogen on the rate of development of spring wheat as measured by degree days. Can. J. Plant Sci. 63:833-846.

Dennis, B., and W.P. Kemp. 1988. Further statistical inference methods for a stochastic model of insect phenology. Environ. Entomol. 17:887-893.

Dennis, B., W.P. Kemp, and R.C. Beckwith. 1986. A stochastic model of insect phenology: Estimation and testing. Environ. Entomol. $15: 540-546$ 
Frank, A.B., and L. Hofmann. 1989. Relationship among grazing management, growing degree-days, and morphological development for native grasses on the Northem Great Plains. J. Range Manage. 42:199-202.

Frank, A.B. 1991. Momhological development of crested and western wheatgrass following grazing. Agron. J. 83:826-828.

Gillen, R.L., and A.L. Ewing. 1992. Leaf development of native bluestem grasses in relation to degree-day accumulation. J. Range Minage. 45:200-204.

Gilmore, E.C. Jr., and J.S. Rodgers. 1958. Heat units as a method of measuring miturity in corn. Agron. J. 50:611-615.

Grace, J. 198S. Temperature as a determinant of plant productivity $p$. 91-107. In: S.P. Long and F.I. Woodward (eds.), Proc. Plants and temperature. Soc. Exp. Biol. Cambridge, England.

Grilz, P.L., J.T. Romo, and J. A. Young. 1994. Comparative germination of smooth brome and plains rough fescue. Prairie Natur. $26: 157-170$.

Harrison, T., and J.T. Romo. 1994. Regrowth of smooth bromegrass (Bromus inernis Leyss.) following defoliation. Can. J. Plant Sci. 74: 531-537.

Holt, E.C., and M.R. Haferkamp. 1987. Growth of introduced temperate legumes in the Edwards Plateau and South Texas Plains. J. Range Manage. 40:132-135.

Hunter, A.F., and M.J. Lechowicz. 1992. Predicting the timing of budburst in temperate trees. J. Appl. Ecol. 29:597-604.
Johnson, I.R., and J.H.M. Thornley. 1985. Temperature dependence of plant and crop processes. Ann. Bot. 55:1-24.

Jordan, G.L., and M.R. Haferkamp. 1989. Temperature responses and calculated heat units for germination of several range grasses and shrubs. J. Range Manage. 42:41-45.

Petersen, R.G. 1985. Design and analysis of experiments. Marcel Dekker, Inc., N.Y..

Pylypec, B. 1986. The Kemen Prairie - A relict fescue grassland near Saskatoon, Saskatchewan. Blue Jay 44:222-231.

Romo, J.T., P.L. Grilz, C.J. Bubar, and J.A. Young. 1991. Influences of temperature and water stress on germination of plains rough fescue. I. Range Manage. 44:75-81.

Rooney, J.M., P. Brain, and S. Yin Loh. 1989. The influence of temperature on leaf production and vegetative growth of Avena fatua. Ann. Bot. 64:469-479.

Sharpe, P.J.H., and D.W. DeMichele. 1977. Reaction kinetics of poikilotherm development. J. Theor. Biol. 64:649-670.

Snedecor, G.W., and W.C. Cochran. 1980. Statistical methods. The Iowa State Univ. Press, Ames.

Thomson, A.J., and S.M. Moncrieff. 1982. Prediction of bud burst in Douglas-fir by degree-day accumulation. Can. J. For. Res. 12:448-452.

Wang, J.Y. 1960. A critique of the heat unit approach to plant response studies. Ecol. 41:785-790.

White, L.M. 1979. Relationship between meteorological measurements and flowering of index species to flowering of 53 plant species. Agr. Meteor. 20:189-204. 